\title{
PENGETAHUAN HYDROTERAPI WUDHU TERHADAP PERKEMBANGAN ANAK DI PUSKESMAS KABUN ROKAN HULU
}

\author{
Dian Cita Sari ${ }^{1, *}$, Ayu Permata ${ }^{1}$, dan Nova Relida ${ }^{1}$ \\ ${ }^{1}$ Dosen Progam Studi Fisioterapi, Fakultas Kedokteran dan Ilmu Kesehatan Universitas Abdurrab, Riau \\ *Email: dian.cita.sari@univrab.ac.id
}

\begin{abstract}
ABSTRAK
Pengaplikasian tatalaksana wudhu secara berkesinambungan akan mendukung perkembangan anak. Lokasi Pengabdian berada kabupaten Rokan Hulu. Dimana dengan luas wilayah Kabupaten Rokan Hulu $\pm 7.498 .2 \mathrm{~km}^{2}$ atau $\pm 7,88 \%$ dari luas wilayah Propinsi Riau $\left(94.561,6 \mathrm{~km}^{2}\right)$. Terdiri dari $85 \%$ daratan dan $15 \%$ daerah perairan dan rawa. Kecamatan terluas wilayahnya adalah Kecamatan Tambusai yaitu 1.127,50 km² (15.04\%) dan Kecamatan terkecil adalah Kecamatan Ujung Batu dengan luas wilayahnya $90,57 \mathrm{~km}^{2}$. $(1,21 \%)$. Menurut data Dinas kesehatan Provinsi Riau, dari 16 Kecamatan di Kabupaten Rokan Hulu, 12 Kecamatan ternyata memiliki puskesmas dengan kriteria terpecil bahkan sangat terpencil, sulit, tertinggal dan perbatasan. Pengabdian ini dipusatkan pelaksanaannya di Puskesmas Kabun, salah satu puskesmas yang berada di kabupaten Rokan Hulu dengan kriteria daerah terpencil, namun memiliki peluang bagi akses kontribusi dalam mendukung program hydroterapi wudhu pada anak usia produktif. Spesifikasi yang dihasilkan dengan Pelaksanaan Progam hydroterapi Wudhu ini merupakan salah satu kunci utama solusi untuk meningkatkan layanan kesehatan bagi anak. Pengabdian ini bertujuan menunjukkan bahwa puskesmas mempunyai dampak positif bagi perkembangan anak sehingga puskesmas mempunyai peran penting dalam melakukan promosi dan intervensi mengenai perkembangan anak.
\end{abstract}

Kata kunci: puskesmas, perkembangan anak, wudhu

\section{ABSTRACT}

Continuous application of wudu management will support child development. Location Dedication is Rokan Hulu district. Where with the area of Rokan Hulu Regency \pm 7.498 .2$ $\mathrm{km} 2$ or $\pm 7.88 \%$ of the total area of Riau Province (94,561,6 km2). It consists of $85 \%$ of land and $15 \%$ of waters and swamp areas. The largest sub-district is Tambusai sub-district which is 1,127,50 km2 (15.04\%) and the smallest is Ujung Batu sub district with $90.57 \mathrm{~km} 2$ area. (1.21\%). According to data from the Riau Provincial Health Office, from 16 sub-districts in Rokan Hulu District, 12 sub-districts have puskesmas with the smallest criteria, even very isolated, difficult, left and border. This devotion is centered on the implementation of Kabun Health Center, one of the health centers located in Rokan Hulu district with the criteria of remote areas, but has an opportunity to access the contribution in supporting hydrotherapy program ablution in children of productive age. The specifications generated with the Implementation of Wudu Hydrotherapy Program are one of the key solutions to improve the health services for children. This dedication aims to show that puskesmas have positive impact for children development so that puskesmas have an important role in doing promotion and intervention about child development.

Key words: Puskesmas, child development, ablution 


\section{PENDAHULUAN}

Berdasarkan pengamatan awal didapatkan bahwa anak mempunyai risiko tinggi mengalami berbagai masalah gangguan kesehatan. Beberapa jenis gangguan yang mungkin akan dialami oleh anak baik secara fisik maupun psikis, seperti kecemasan, gangguan stres paska trauma, gangguan kepribadian, sulit berinteraksi, penurunan berat badan/ berat badan dibawah ideal, dan kekurangan gizi. Fenomena tersebut juga tampak dari beberapa penelitian serupa, yang sebelumnya dilakukan di berbagai negara. Sebagai contoh, Tonge dkk. (1996) menemukan bahwa terdapat rata-rata 40\% gangguan emosional dan perilaku pada anak di Australia. Temuan ini didukung oleh penelitian di Kanada oleh Balogh dkk. (2010) yang mengemukakan bahwa anak berisiko 15 kali lebih tinggi untuk dirawat di Rumah Sakit dibanding populasi dewasa pada umumnya. Hudson dan Chan (2002) menyebutkan tiga hambatan utama perkembangan anak, yaitu kurangnya pengetahuan praktisi kesehatan mengenai seluk-beluk anak, kurangnya ahli yang khusus mendalami masalah ini, serta hambatan komunikasi antara klinisi dan individu.Salah satu cara yang bisa dilakukan untuk mengoptimalkan perkembangan anak adalah dengan berwudhu pada setiap aktivitas utama karena jika wudhu yang dilakukan dengan penuh kesungguhan, khusyu', tepat, ikhlas dan kontinu, dapat menumbuhkan kenyamanan, persepsi dan motivasi positif, mengefektifkan coping, dan respons emosi positif.

Dari analisis awal, progam yang difokuskan dalam pengabdian ini adalah dengan Progam hydroterapi Wudhu. Ini merupakan salah satu kunci utama solusi untuk meningkatkan layanan kesehatan bagi anak. Pengabdian ini bertujuan menunjukkan bahwa puskesmas mempunyai dampak positif bagi perkembangan anak sehingga puskesmas mempunyai peran penting dalam melakukan promosi dan intervensi mengenai perkembangan anak.

\section{TINJAUAN PUSTAKA}

\subsection{Data Dinas Kesehatan Rokan Hulu}

Dalam rangka mencapai tujuan pembangunan kesehatan diharapkan dapat lebih mengarah pada kegiatan konkrit yang berdampak semakin meningkatnya derajat kesehatan masyarakat yang pada gilirannya meningkatkan kualitas bangsa secara keseluruhan yang memberikan sumbangan nyata dalam meningkatkan daya saing bangsa khususnya dalam era globalisasi dewasa ini.

Untuk mengejar ketertinggalan kita dalam pembangunan di bidang kesehatan, jajaran kesehatan kabupaten Rokan Hulu telah bertekad untuk membangun kesehatan masyarakat Rokan Hulu dengan Visi "Rokan Hulu Sehat" yaitu sebagai gambaran masyarakat Rokan Hulu yang memiliki derajat kesehatan tertinggi di Propinsi Riau

Kabupaten Rokan Hulu dengan Ibu kota Pasir Pengaraian terletak dalam wilayah Provinsi Riau dan terbentuk sebagai hasil pemekaran dari Kabupaten Kampar sejak tahun 1999, berdasarkan UU No. 53 tahun 1999 Jo Undang-Undang No. 11 tahun 2004 dan Keputusan Menteri Dalam Negeri Nomor 75 tahun 1999 kemudian diubah terakhir dengan No. 34 tahun 2008. Pada awal berdirinya Kabupaten Rokan Hulu terdiri dari 7 Kecamatan meliputi 80 Desa dan 6 Kelurahan. Pada tahun 2014 memiliki 16 kecamatan terdiri dari 153 Desa dan 6 Kelurahan

Secara geografis, Kabupaten Rokan Hulu terletak diantara $100^{\circ}-101^{\circ} 52^{\prime}$ Bujur Timur dan $0^{\circ}-1^{\circ} 30^{\prime}$ Lintang Utara. Luas wilayah Kabupaten Rokan Hulu \pm 7.498 .2 km² atau $\pm 7,88 \%$ dari luas wilayah Propinsi Riau $\left(94.561,6 \mathrm{~km}^{2}\right)$, yang terdiri dari $85 \%$ daratan dan $15 \%$ daerah perairan dan rawa. Kabupaten Rokan Hulu terdiri dari 16 Kecamatan. Kecamatan terluas wilayahnya adalah Kecamatan Tambusai yaitu 1.127,50 
$\mathrm{km}^{2}(15.04 \%)$ dan Kecamatan terkecil adalah Kecamatan Ujung Batu dengan luas wilayahnya $90,57 \mathrm{~km}^{2} .(1,21 \%)$

Di Kabupaten Rokan Hulu terdapat beberapa sungai, 2 diantaranya adalah sungai yang cukup besar yaitu sungai Rokan Kanan dan sungai Rokan Kiri. Selain sungai besar tersebut, terdapat juga sungai-sungai kecil antara lain Sungai Tapung, Sungai Dantau, Sungai Ngaso, Sungai Batang Sosa, Sungai Batang Kumu, sungai Duo (langkitin) dan lain-lain, sungai Rokan Kanan dan Sungai Rokan Kiri yang panjangnya $\pm 400 \mathrm{~km}$ dengan kedalaman rata-rata $6 \mathrm{~m}$ dan lebar rata-rata 92 meter. Sedangkan dibagian hilir sungai ini termasuk daerah Kabupaten Rokan Hilir. Aliran sungai Rokan Kanan melalui Kecamatan Bangun Purba, Rambah, Rambah Hilir, Kepenuhan, sedangkan sungai Rokan Kiri yang Hulunya di kecamatan Rokan IV Koto, Ujung Batu, Kunto Darussalam. Sungai-sungai yang terdapat di kabupaten Rokan Hulu ini sebagian masih berfungsi baik sebagai prasarana perhubungan, sumber air bersih dan budi daya ikan.

Secara demografi penyebaran penduduk di kabupaten Rokan Hulu tidak merata. pertumbuhan penduduk paling tinggi dalam satu dasawarsa terakhir berada di Kecamatan Tambusai Utara dengan jumlah 87.896 orang, kemudian Kecamatan Tambusai yang mencapai 61.656 orang, tingginya jumlah penduduk di dua Kecamatan itu disebabkan daerah tersebut merupakan wilayah yang terluas dibanding Kecamatan lainnya. Selain itu, karena Kecamatan Tambusai dan Tambusai Utara merupakan areal perkebunan dan pabrik kelapa sawit yang dimiliki oleh beberapa perusahaan, Laju pertumbuhan penduduk itu sepertinya terjadi karena semakin banyaknya perusahaan perkebunan kelapa sawit, sehingga harus membutuhkan tenaga kerja, dan biasanya dicari dari warga luar Kabupaten Rokan Hulu. Sedangkan pertumbuhan penduduk di ibu kota Kabupaten Rokan hulu yaitu Kecamatan Rambah berada pada urutan ke-lima yang mencapai 49.744 orang, sedangkan jumlah terendah penduduknya berada di Kecamatan Pendalian IV Koto yang hanya 13.345 orang. karena selain wilayahnya sempit juga karena hanya murni penduduk asli.

Tabel 2. Jumlah Penduduk setiap Kecamatan di Rokan Hulu

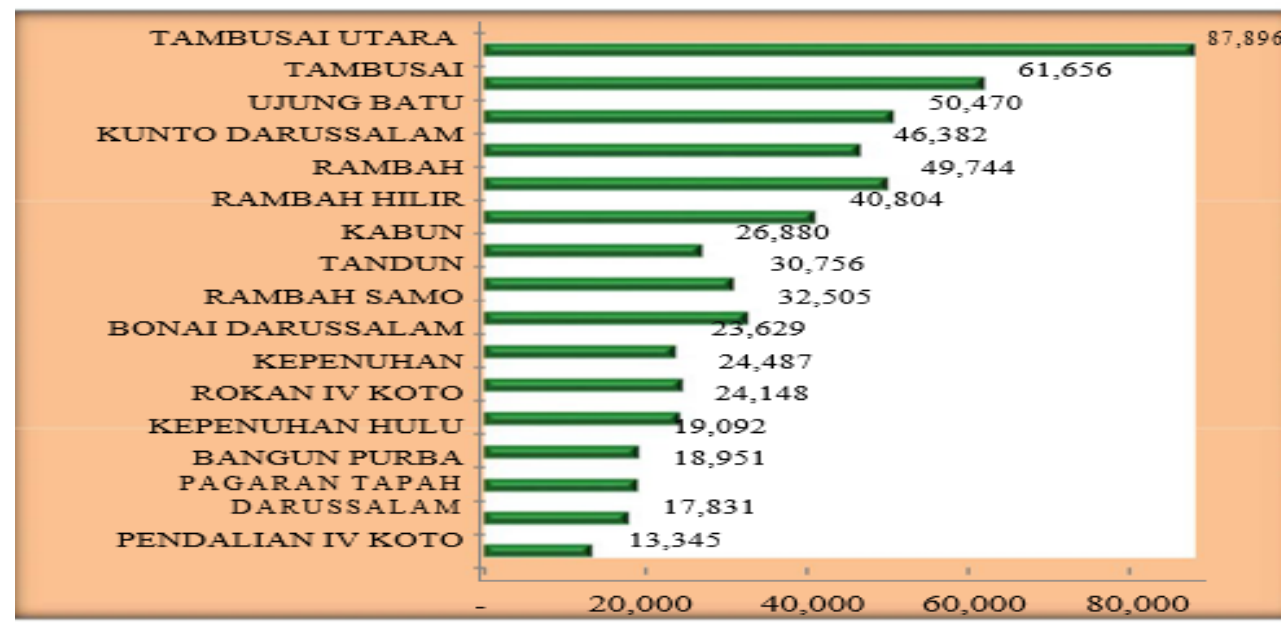

Kepadatan penduduk yang berbeda di setiap kecamatannya, antara lain kecamatan Ujung Batu yang memiliki luas terkecil yaitu $90.57 \mathrm{Km}^{2}$ memiliki kepadatan penduduk tertinggi sebesar 557,25 per $\mathrm{Km}^{2}$, sedangkan Kecamatan Rokan IV Koto dengan luas wilayah 904,07 $\mathrm{km}^{2}$ memiliki kepadatan penduduk yang paling rendah yaitu 26,71 per $\mathrm{Km}^{2}$ dan Kecamatan Rambah yang terletak di ibukota kabupaten Rokan Hulu dengan luas wilayah 396,66 km² memiliki tingkat kepadatan tertinggi ke lima sebesar 125 per $\mathrm{Km}^{2}$ dan Kabupaten Rokan hulu dengan luas wilayah sekitar 7.498,2 kilometer persegi yang 
didiami 568.576 orang, rata-rata tingkat kepadatan penduduk sekitar 76 per $\mathrm{Km}^{2}$. Distribusi penduduk Laki-laki dan perempuan menurut kelompok umur lebih banyak pada kelompok umur produktif (15-64 tahun) 359.515 jiwa (62,23\%) dari pada kelompok umur tidak produktif (0-14 tahun dan $\geq 65-75+) 209.061$ jiwa $(36,77 \%)$, tingginya persentase penduduk usia produktif merupakan potensi sumber daya manusia bagi kabupaten Rokan Hulu, perbandingan jumlah penduduk usia produktif terhadap jumlah usia tidak produktif ini menunjukkan beban tanggungan.

Di Kabupaten Rokan Hulu penduduk Laki-laki berjumlah lebih banyak dibandingkan perempuan yaitu (Sex rasio 107,63), Dengan kata lain terdapat 107,63 jiwa jenis kelamin laki-laki untuk setiap 100 jiwa penduduk dengan jenis kelamin perempuan. Secara keseluruhan di 16 kecamatan jumlah penduduk Laki-laki lebih banyak dibandingkan perempuan. Berdasarkan SK Bupati No 26 tahun 2013 bahwa di kabupaten Rokan hulu memiliki beberapa wilayah kerja puskesmas yang tergolong daerah terpencil dan sangat terpencil yang memerlukan perhatian khusus antara lain:

Tabel 2. Data Puskesmas Terpencil di Rokan Hulu

\begin{tabular}{r|l|l|l}
\hline No & \multicolumn{1}{|c|}{ Puskesmas } & \multicolumn{1}{c}{ Kecamatan } & \multicolumn{1}{c}{ Kriteria } \\
\hline 1 & Rambah Hilir II & Rambah Hilir & Terpencil \\
\hline 2 & Kabun & Kabun & Terpencil \\
\hline 3 & Rokan IV Koto I & Rokan IV Koto & Terpencil \\
\hline 4 & Rokan IV Koto II & Rokan IV Koto & Sangat Terpencil \\
\hline 5 & Pendalian IV Koto & Pendalian IV Koto & Sangat Terpencil \\
\hline 6 & Kunto Darussalam & Kunto Darussalam & Terpencil \\
\hline 7 & Kepenuhan & Kepenuhan & Terpencil \\
\hline 8 & Kepenuhan Hulu & Kepenuhan Hulu & Terpencil \\
\hline 9 & Tambusai Utara I & Tambusai Utara & Terpencil \\
\hline 10 & Tambusai Utara II & Tambusai Utara & Terpencil \\
\hline 11 & Bangun Purba & Bangun Purba & Terpencil \\
\hline 12 & Bonai Darussalam & Bonai Darussalam & Terpencil \\
\hline
\end{tabular}

Dari tabel diatas menunjukkan bahwa sekitar 75\% wilayah kerja Puskesmas merupakan daerah sulit dan terpencil. Hal ini dapat menjadi acuan para pengambil kebijakan agar memprioritaskan pembangunan kesehatan diwilayah tersebut sesuai dengan RPJM Nasional untuk lebih memperhatikan daerah terpencil, sulit, tertinggal dan perbatasan. Spesifikasi yang akan dihasilkan adalah dengan Progam hydroterapi Wudhu yang dilaksanakan ini merupakan salah satu kunci utama solusi untuk meningkatkan layanan kesehatan bagi anak. Pengabdian ini bertujuan menunjukkan bahwa puskesmas mempunyai dampak positif bagi perkembangan anak sehingga puskesmas mempunyai peran penting dalam melakukan promosi dan intervensi mengenai perkembangan anak.

\subsection{Hidroterapi Wudhu dan peranannya dalam perkembangan anak}

Kata wudhu diambil dari kata wadāah, yang artinya baik, bersih, murni atau tidak kecampuran dosa. Pengaruh wudhu sangat dalam, hingga wudhu dapat menumbuhkan persepsi dan motivasi positif, mengefektifkan coping, respons emosi positif, serta dapat menghindarkan reaksi stres.Bagian tubuh yang terkena air wudhu adalah bagian tubuh yang terbuka, yang sering dihinggapi bakteri dan virus yang menyebabkan penyakit, sehingga bagian itu harus dibersihkan agar terhindar dari 
berbagai penyakit. Bahar Azwar, spesialis bedah umum dan supersialis bedah onklogi dari Rumah Sakit Cipto Mangunkusumo mengatakan bahwa, "Wudhu adalah pembilasan serta pengenceran kuman hingga mengurangi keganasannya, serta mempermudah regenerasi kulit dan selaput lendir. Dengan mudahnya regenerasi kulit dan selaput lendir tersebut, tubuh tidak akan mudah terserang penyakit karena kulit dan selaput lendir yang menjadi gugus depan perlindungan tubuh dapat menjalankan tugasnya dengan baik, yaitu menghancurkan penyakit yang akan menggerogoti tubuh.

Dengan wudhu secara lahiriah akan memunculkan kebersihan. Sementara itu bagi anggota tubuh yang tidak terkena langsung oleh basuhan air wudhu, maka bisa dilakukan wudhu secara batiniah.Dibalik persyari'atan wudhu, terdapat lautan hikmah manakala kita kaji. Satu dimensi diantaranya adalah wudhu dalam perspektif ilmu kesehatan yang memiliki efek terapi holistik melalui meridian dan titik-titik akupuntur yang terdapat pada seluruh anggota wudhu. Maka kenikmatan yang tiada ternilai tersebut dapat terungkap dan diraih. Pengaplikasian tata laksana wudhu secara berkesinambungan dalam peningkatan motivasi belajar menjadi kaya dan mendalam terlebih ditinjau dalam kaitannya dengan pendidikan Islam. Beberapa aspek perkembangan anak yang terpengaruhi oleh wudhu, yaitu:

a) Psikis : Wudhu memberikan ketenangan jiwa yang mampu menerapi segala kegundahan masalah dan ketegangan saraf. Air wudhu yang suci akan meresap masuk kedalam akal dan hati, sehingga dapat menata emosi dengan baik. Wudhu dapat mengosongkan emosi dari pengaruh-pengaruh yang buruk, sekaligus dapat melesatkan emosi positif dalam diri.

b) Fisik : Secara medis, wudhu mampu memberikan nutrisi kesehatan yang dibutuhkan oleh manusia. Ulama fikih mengungkapkan bahwa manfaat wudhu adalah upaya memelihara kesehatan tubuh. Daerah yang dibasuh dalam wudhu memang paling banyak bersentuhan dengan benda-benda asing, termasuk kotoran. Karena itu wajar kalau daerah itu yang harus dibasuh. Menurut Dr. Magomedov, wudhu mampu melakukan dua hal penting bagi kesehatan manusia, yaitu wudhu mampu mencegah datangnya penyakit maupun mengobati penyakit.Diriwayatkan dari Rafi' bin Khadij r.a katanya: aku pernah mendengar Rasulullah SAW bersabda: sesungguhnya kepanasan demam itu adalah panas dari uap neraka jahanam, maka dinginkanlah dengan air."(HR. Bukhori, Muslim, Tirmidzi, Ahmad, dan Ad-Darimi).

Jika melihat hadits Rasulullah yang mendorong berwudhu dan menganjurkan untuk membiarkan air wudhu sampai kering sendiri, kemudian kita kaitkan dengan hadits Rasulullah yang berbunyi: "demam adalah panas dari uap neraka jahanam, dinginkanlah dengan air". Maka fakta ilmiah bahwa berwudhu bagi orang yang terjangkiti demam merupakan cara yang paling tepat untuk mengatasi suhu tubuh yang tinggi tanpa harus merendam di air/ mengompres dengan air dingin, karena hal tersebut merupakan tindakan yang tidak efektif; apalagi sampai mendapatkan hasil positif..Bagi mereka yang sering melakukan wudhu secara ikhlas, terbiasa, tepat, dan kontinu, baginya memperoleh manfaat positif dari wudhu yang dilakukannya. Sebab orang yang menjalankan wudhu mampu beradaptasi dan mempunyai coping yang efektif, maka perubahan irama sirkadian dapat diterima sebagai stimulator untuk berprestasi, bermanfaat bagi kesehatan fisik dan psikis.

\section{BAHAN DAN METODE}


Dalam rangka mencapai tujuan yang telah diuraikan di atas, maka pelaksanaan kegiatan pengabdian kepada masyarakat ini dilakukan dengan metode ceramah dan diskusi yaitu memberikan penjelasan dan praktik dari apa yang telah disampaikan. Ada dua metode yang di terapkan dalam program ini, yaitu metode presentasi, dan metode demonstrasi. Metode presentasi diterapkan untuk memperkenalkan Hydroterapi wudhu dan perkembangan anak. Kemudian penjabaran serta kemanfaatannya dan penerapanya dalam meminimalisir gangguan perkembangan anak. Metode demonstrasi untuk pengoperasionalisasi program sehingga dapat menjadi bekal pembelajaran ilmu kesehatan anak pada warga. Adapun langkah-langkah dalam pelaksaan program pelatihan ini adalah:

1. Pra Kegiatan

a. Proses perijinan dimulai dengan membuat surat ijin dari universitas di tujukan aparat desa terkait tempat pengabdian dilakukan untuk melaksanakan program, Sekaligus meminta bantuan untuk memeperoleh data warga yang akan mengikuti program sosialisasi dan pelatihan.

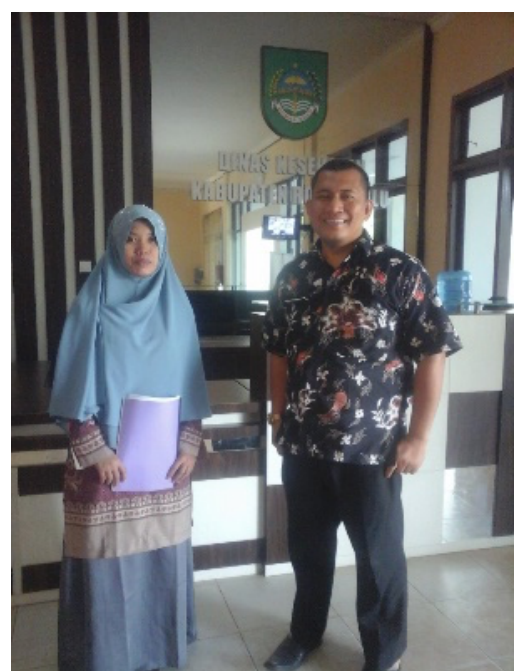

Gambar 1. Pengurusun Izin dengan Kasubag Umum DinKes Rohul

b. Persiapan tempat di lakukan di ruangan aula puskesmas kabun, Rokan Hulu sekaligus perlengkapan pelatihan pada setiap kursi peserta.

c. Persiapan alat, bahan dan perlengkapan dalam program ini dari mulai spidol, penghapus, modul, banner, laptop, papan tulis, dan bolpoint. Penyusunan alat evaluasi berupa daftar kehadiran, lembar latihan, lembar contoh lembar pertanyaan.

\section{Pelaksanaan kegiatan}

Setelah memeperoleh ijin dari pihak terkait serta diperolehnya data dari peserta maka dilaksanakan sosialisasi program dengan peserta dan instansi terkait, lalu dibuat kesepakatan mengenai waktu pelaksanaan.

Program dilakukan dalam bentuk penyuluhan dalam beberapa tahap. Tahap I : Pengenalan materi program hydroterapi wudhu dan perkembangan anak Tahap II :Mendemonstrasikan materi dan berdiskusi

\section{HASIL DAN PEMBAHASAN}

Pengabdian ini dilaksanakan dengan tujuan untuk meningkatkan peran serta Fakultas Kedokteran dan ilmu kesehatan, Khususnya Progam studi Fisioterapi Universitas Abdurrab dalam memberikan pemahaman tentang konsep hydroterapi wudhu secara tepat dalam bidang 
pendidikan dan kesehatan. Juga untuk meningkatkan pemahaman pengetahuan hydroterapi wudhu pada warga puskesmas kabun, Rokan hulu, sehingga warga sadar hikmahnya pada perkembangan anak. Pengabdian ini berlokasi di puskesmas kabun Rokan Hulu. Prosedur yang dilakukan dalam Pengabdian ini adalah perkenalan dengan anak-anak yang berada dalam lingkungan puskesmas kabun pada hari pertama pengabdian, kemudian pada hari kedua pengabdian dengan izin dari instansi terkait, tim memberikan materi fisioterapi wudhu kepada kelompok peserta anak-anak dan sebelum memasuki ruang tersebut tim pengabdian terlebih dahulu melakukan observasi wudhu peserta yang berada didalam ruang belajar bersama dengan petugas kesehatan dari puskesmas.

Semua informasi yang didapatkan para petugas kesehatan gunakan sebagai acuan untuk mendesain pembelajaran yang menggunakan pengetahuan Hydroterapi Wudhu untuk pendidikan dan kesehatan anak mulai dari pre-activity, whilst activity sampai dengan post activity. Pada tahap ini, para peserta dilatih untuk dapat mendesain pembelajaran sendiri sesuai dengan contoh yang diberikan oleh narasumber. Para peserta yang berjumlah 15 orang dikelompokkan menjadi 3 kelompok, dan masing-masing kelompok terdiri atas 5 orang anggota. Mereka diberikan tugas untuk bahasan pengetahuan hydroterapi wudhu dengan tema yang berbeda-beda. Semua peserta yang ikut dalam pelatihan ini secara aktif dan antusias mengerjakan tugas, dan mereka saling berbagi untuk mengerjakan bagian-bagian pembelajaran hydroterapi wudhu. Ada yang mengerjakan di bagian membuka pelajaran, ada yang mengerjakan di bagian pelaksanaan inti pembelajaran, dan ada yang mengerjakan di bagian penutup.

\section{KESIMPULAN}

Program pengabdian ini bermanfaat sebagai sumber daya yang strategis oleh berbagai pihak terutama para pengambil kebijakan, dalam membuat perencanaan, pelaksanaan program dan mengevaluasi upaya-upaya kesehatan melalui hidroterapi wudhu. Progam penyuluhan tentang perkembangan anak oleh puskesmas yang ada saat ini masih belum dapat memenuhi kebutuhan data dan informasi kesehatan secara optimal.

Banyak faktor yang mempengaruhi penyelenggaraan kesehatan anak, untuk itu kedepannya program pengabdian di kabupaten Rokan Hulu hendaknya lebih banyak lagi terlaksana, tentunya dengan semangat kemitraan antar semua pelaku pembangunan, baik pemerintah secara lintas sektor, badan legislatif dan yudikatif, serta masyarakat termasuk swasta. Sehingga penyelenggaraan pembangunan kesehatan dapat dilaksanakan dengan berhasil guna dan berdaya guna, dengan interaksi, interelasi, serta keterpaduan berbagai upaya yang dilakukan.

Untuk mengurangi kesenjangan dan mengantisipasi timbulnya berbagai masalah kesehatan anak yang semakin kompleks maka dimasa depan perlu upaya strategis sehingga mampu menjawab tantangan dan permasalahan yang dihadapi. Untuk itu kami menyarankan hal-hal sebagai berikut :

1. Upaya penyuluhan hidroterapi wudhu ini hendaknya lebih merata, terjangkau, bermutu dan memprioritaskan upaya Promotif Preventif, juga upaya Kuratif dan Rehabilitatif .

2. Menyediakan sarana dan prasarana pelayanan kesehatan khususnya di daerah pedesaan dan daerah terpencil agar pelayanan kesehatan lebih merata dan terjangkau oleh masyarakat.

3. Diperlukannya terobosan baru dalam membuat rencana program, baik metoda maupun tehnik yang sesuai. 


\section{DAFTAR PUSTAKA}

Abdullah, Sayid bin Alwi bin Muhammad Al Haddad, 2014, Risalatul Mu'awamah, AlHidayah, Surabaya

Akrom, Muhammad, 2010, Terapi Wudhu :Sempurna Shalat, Bersihkan Penyakit, Mutiara Media, Yogyakarta

Alsa, Asmadi, 2011, Pendekatan Kuantitatif dan Kualitatif serta Kombinasinya, Pustaka Pelajar, Yogyakarta

Bungin, Burhan,2012, Penelitian Kualitatif Edisi Kedua, Kencana Media, Jakarta

El-Bantanie, Muhammad Syafiie, 2010, Dahsyatnya Terapi Wudhu, Media Quanta, Jakarta

Hasanuddin, Oan, 2007, Mukjizat Berwudhu untuk Penyembuhan dan Pencegahan Penyakit, Quantum Media, Jakarta

Jalaluddin, 2010, Psikologi Agama, Rajawali Pers, Jakarta

Kementerian Agama RI, 2012, Al-Qur'an dan Tafsirnya Jilid 2, PT. Sinergi Pustaka, Jakarta

Mahfan, 2015, Kamus Lengkap 3 Bahasa (Arab,Inggris dan Indonesia)", Sandro Jaya, Jakarta

Muhaimin dkk. 2009, "Manajemen Pendidikan, Aplikasi dalam Penyusunan Rencana Pengembangan Sekolah/ Madrasah", Kencana Media, Jakarta 